\title{
Exchange Rate, Interest Rate and Ricardian Equivalence Hypothesis: Evidence from Nigeria
}

\author{
Chika Felicia Abada \\ Social Sciences Unit, School of General Studies, University of Nigeria Nsukka \\ Felicia.abada@unn.edu.ng
}

\section{Doi:10.5901/mjss.2016.v7n5p58}

\begin{abstract}
The validity of Ricardian Equivalence Hypothesis (REH) in Nigeria has been tested by bringing into play quarterly data of exchange and interest rates. The study was motivated basically by the need to examine the short and long run dynamics between the variables streaming from exchange and interest rates to government budget deficit and government debt using Autoregressive Distributed Lag (ARDL) bounds technique developed by Pesaran, Shin and Smith. The estimation results from Wald-test confirmed that, government budget deficit and government debt are not equal to zero. Therefore, the null hypothesis of REH holding in Nigerian has been refuted in order to uphold the efficacies of fiscal policy in macroeconomic stabilization. To this effect, it become obvious that Nigerian consumers respect the performance of fiscal policy and treat government debt as net wealth by increasing their consumption once there is a rise in income either via debt or tax cut.
\end{abstract}

Keywords: Ricardian equivalence hypothesis, exchange rate, interest rate, Autoregressive distributed lag bound test, microeconomics

\section{Introduction}

The current debate in both developing and developed economies is the challenge posed by large budget deficits and substantial government debt which attracted the attention of policy makers to the question of how much and fast shortfall can be reduced to revamp an economy. In terms of budget deficit, government sponsors its expenditure by raising taxes, borrowing and printing new currencies which have consequential influence on macroeconomic variables such as interest rate and exchange rate of the country.

The Keynesian school of thought argues that consumers treat government debt as net wealth because swap in the use of tax for debt influences private aggregate demand particularly private consumption positively (Marinheiro, 2001; Afonso, 2008; Afzal, 2012). This led to the crowding out of private investment as a result of the fall in private and national savings which have been predicated by an increase in real interest rate. The drop in capital accumulation could stimulate fall in the long-run growth of the economy.

The Ricardian equivalence hypothesis (REH) held a contrary view. The REH sometimes called Barro-Ricardo Equivalence Hypothesis upholds that, consumers treat or consider government debt as future tax liability (Barro,1974). Hence, any tax cut now will not increase consumption expenditure but savings since present borrowings will increase future tax on their generations. This behaviour is exhibited by consumers on account that, after the maturity of the borrowed funds, government has to repay with interest as tax by the new generation. According to Afonso (2008), the new generation can be exonerated if consumers buy bonds and fail to regards them as acquired wealth. Thus, private savings increase by equal amount as budget deficit while national savings remain unaltered, private investment will not be crowded out.

The most emphatic idea behind REH is that, government debt and lump-sum taxes have an equivalent way of financing public expenditure (Afzal, 2012). By implication, Nigerian consumers behave in Ricardian or Keynesian model to be fiscally effective (Adji, 2007). Thus, if Nigerian consumers are Ricardian, government debt is not considered as net wealth and fiscal policy become ineffective in macroeconomic stabilization. The connection between budget deficit and interest rate can be linked to Mundell- Flemming model which hypothesizes that, rise in interest rate and exchange rate as well as capital inflows is deduced by an increase in budget deficit.

In the early 1990s, budget deficit in Nigeria escalated. Budget deficit rose from N7, 414.3m in 1991 to N70, 270.6m in 1994. This trend continued between 2005 and 2013. It rose from N161,406.30m in 2005 to N1067121.25m in 2013. Interest rate on the other hand had series of ugly changes in Nigeria over time. It surged from 27.7 per cent in 1990 to 36.09 in 1993 and nose-dived in 1994 to 21.0.Between 2005 and 2013, the interest rate was inconsistent The inconsistency in interest rate can be observed between 2005 and 2013 as 13.00, 12.25, 8.75, 9.81, 7.44, 6.13, 9.13, 9.19, 


\subsection{0 and 10.60 accordingly (CBN, 2014).}

In Nigeria, only few literature have tested issues related to REH. For instance, Likita, (2014); Oseni and Olomola, (2013); Akanbi (Undated); Orji, Onyeze and Edeh, (2014) have keen reference to budget deficit, national saving and private consumption by employing Vector Autoregressive (VAR), Ordinary least Square (OLS) and Two stage Least Square (2SLS) while exchange and interest rate got limited attention. Also, most empirical evidence for REH are commonly estimated using two approaches. Firstly, the impact of government deficits on interest rates. Secondly, the effect of fiscal policy variables (public debt and tax) on aggregate economic variables such as consumption and savings (Tito, Geraldo \& Fernando, 2011; Rodrigues, 2006). To this effect, the study become pertinent in Nigeria in order to appraise the validity of using REH to determine the impact of budget deficit and government debt have on exchange and interest rate in Nigeria. Autoregressive Distributed Lag (ARDL) bound test technique was used.

\section{Data Source and Empirical Methodology}

\subsection{Data Description}

In this study, high frequency data (quarterly) from the first quarter of 1981 to the fourth quarter of 2013 were drawn from Central Bank of Nigeria (CBN, 2014) statistical bulletins and statement of accounts to be interpolated from annual to quarterly series. The data of interest in this study are exchange rate (ER), interest rate (IR), Government budget deficit (Gd) and Government debt (Db). From these variables, two models are formulated with each based on the underlying constraints that must be satisfied in order to guarantee the validity of REH in Nigeria.

To affirm if government budget deficit and government debt affect exchange rate in Nigeria, the model can be specified as: $E R_{t}=f\left(G d_{t}, D b_{t}\right)-------------------------------(2.1)$

This can be stated in an estimable form as:

$E R_{t}=\alpha_{0}+\alpha_{1} G d_{t}+\alpha_{2} D b_{t}+\mu_{t}---------------------------(2.2)$

From equation 2.2, exchange rate is the dependent variable while government budget deficit $(G d)$ and government debt $(D b)$ proxied by the sum of consolidated external and domestic debts are the control variables while ${ }^{\mu_{t}}$ denotes the stochastic error term. In respect to interest rate, the following model can be developed having interest rate (IR) as the dependent variable while other variables remained as explained in equation 2.2. This can be specified as:

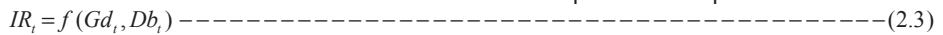

It can be estimably expressed as:

$$
I R_{t}=\varphi_{0}+\varphi_{1} G d_{t}+\varphi_{2} D b_{t}+\mu_{t}------------------------------------(2.4) \text { Where } \mu_{t} \text { is the }
$$

stochastic error term, $\varphi_{0}$ as the intercept while $\varphi_{1}$ and $\varphi_{2}$ are the coefficients of the parameter estimate with interest rate as the dependent variable.

\subsection{Econometric methodology}

To determine whether long-run and short-run associations exist among the variables in equations 2.2 and 2.4 above, Autoregressive Distributed Lag (ARDL) bound cointegration technique established by Pesaran et al, (2001) will be employed. The choice of this model is informed by the merits it has over other symmetric cointegration test. The ARDLbound test is preferable to other Cointegrating tests such as Engle and Granger (1987) and Johansen and Juselius (1995) because it has less emphasis on pre-test on the variables and therefore applicable whether the variables are purely I(0), I(1) or fractionally cointegrated (Pesaran et al. 2001); also, it is more preferable because the error correction term can be drawn by simple linear conversion from ARDL model (Banerjee, Dolado, Galbraithand \& Hendry, 1993). The ARDL method is more efficient when used on small or limited sample size. Equally, the short and long run parameters can be estimated simultaneously and finally, it is applied on time series data that can adjust to structural breaks (Pesaran, et al, 2001). In the presence of I (2) variables, the decision criteria table provided by Pesaran et al. (2001) ceased to be valid because bound tests are guided by the assumption of the variables being either I(1) or I(0) process (Quattara, 2004). The critical values for I (1) series are referred to as upper bounds while is lower bounds for I(0) series.

To affirm if REH holds in Nigeria, Autoregressive Distributed Lag (ARDL) Bound Test as developed by Pesaran et al. (2001) will be used on equations 2.2 and 2.4. It is a dynamic unrestricted error correction model (UECM) that can be explicitly driven from the ARDL bounds test by way of a simple linear conversion of short-run and long-run dynamic equilibrium created without losing any relevant long-run information. 
From equation 2.2 and 2.4 above, the ARDL bound approached can be employed to estimate if government budget deficit and public debt affect exchange and interest rates in Nigeria as:

$$
\begin{gathered}
E R_{t}=\lambda_{0}+\lambda_{1} E R_{t-1}+\lambda_{2} G d_{t-1}+\lambda_{3} D b_{t-1}+\sum_{t=z}^{p} \lambda_{21} \Delta E R_{t-2}+\sum_{t=r}^{p} \lambda_{22} \Delta G d_{t-r}+\sum_{t=f}^{p} \lambda_{23} \Delta D b_{t-f}+\mu_{t t}---(2.5) \\
I R_{t}=\phi_{0}+\phi_{1} I R_{t-1}+\phi_{2} G d_{t-1}+\phi_{3} D b_{t-1}+\sum_{t=h}^{p} \phi_{21} \Delta I R_{t-h}+\sum_{t=k}^{p} \phi_{22} \Delta G d_{t-k}+\sum_{t=x}^{p} \phi_{23} \Delta D b_{t-x}+\mu_{2 t}----(2.6)
\end{gathered}
$$

From equations 2.5 and 2.6 above, where $\lambda_{0}, \phi_{0}$ represent the intercepts, $\lambda=1-3$ and $\phi=1-3$ represents long run estimate of the parameter, $\lambda=21-23$ and $\phi=21-23$ describes the short run dynamic coefficients for model one and two while $\Delta$ depicts the first difference operator, $p$ describe the maximum lag length decided by Schwarz Bayesian Information Criterion (SBC) and $\mu_{1 t} \mu_{2 t}$ are the white noise error terms.

In order to affirm if long-run relationship exist among the variables in equations 2.5 and 2.6, the joint significance of the lagged levels of the variables can be decided using ARDL-bound cointegration test. For Ricardian Equivalence Hypothesis to hold in Nigeria, the following restrictions of null hypothesis must be met for model one and two respectively as:

$$
\lambda_{2}=\lambda_{3}=0 \text { and } \phi_{2}=\phi_{3}=0
$$

This null hypothesis explains that, for REH to hold, Government budget deficit ( $G d$ ) and Government debt $\left({ }^{D b}\right)$ must not have influence on exchange and interest rates.

More importantly, after estimating equations 2.5 and 2.6, the Wald test (F-statistic) is computed to affirm if Government budget deficit ( $G d$ ) and Government Debt $(D b)$ have impact on exchange and interest rates in Nigeria. The F-test is computed for the joint coefficients of the lagged levels of the variables and comparing same to the critical bound values obtained in Pesaran et al, (2001). In the critical table developed by Pesaran et al. (2001), two sets of appropriate critical values in which one set assumes all explanatory variables to be I(1) and the other assumes the explanatory variables to be I(0) process are provided. If the calculated F-statistic is found to be above the upper bound I(1), the null hypothesis is rejected and incite the conclusion that co-integration exists. On the other hand, if the calculated F-statistic is below the lower bound, it indicates no co-integration, hence; do not reject the null hypothesis. Consequently, it is inconclusive if the F-statistic lie in between the lower and upper critical bounds. If exist a long-run relationship among the variables as evidenced by the test results, the long-run model of exchange and interest rate will be evaluated using ARDL $(\mathrm{m}, \mathrm{n}, \mathrm{h})$ as:

$$
\begin{aligned}
& E R_{t}=\Psi_{0}+\sum_{t=i}^{m} \Psi_{1 i} E R_{t-i}+\sum_{t=i}^{n} \Psi_{2 i} G d_{t-i}+\sum_{t=i}^{h} \Psi_{3 i} D b_{t-i}+\mu_{1 t}----------------(2.7) \\
& I R_{t}=\theta_{0}+\sum_{t=i}^{m} \theta_{1 i} I R_{t-i}+\sum_{t=i}^{n} \theta_{2 i} G d_{t-i}+\sum_{t=i}^{h} \theta_{3 i} D b_{t-i}+\mu_{2 t}---------------(2.8)
\end{aligned}
$$

All the variables from equations 2.7 and 2.8 are as explained above while $\Psi_{0}, \theta_{0}$ denotes the intercepts, $\Psi=1 i-3 i$ and $\theta=1 i-3 i$ represent the long-run multipliers of the parameter estimates and the number of lags $(m, n, h)$ will be decided by the SBC. If the long-run multipliers of the parameter estimates are accomplished, the short-run dynamic error correction model (ECM) of ARDL for exchange and interest rates will be investigated using equations 2.9 and 2.10 as:

$$
\begin{aligned}
& \Delta E R_{t}=\varphi+\sum_{p=1}^{m} \varpi_{p} \Delta E R_{t-p}+\sum_{f=1}^{n} \varpi_{f} \Delta G d_{t-f}+\sum_{v=1}^{h} \varpi_{v} \Delta D b_{t-v}+\delta E C M_{t-1}+\varepsilon_{1 t}--------(2.9) \\
& \Delta I R_{t}=\alpha+\sum_{p=1}^{m} \Omega_{p} \Delta I R_{t-p}+\sum_{f}^{n} \Omega_{f} \Delta G d_{t-f}+\sum_{v}^{h} \Omega_{v} \Delta D b_{t-v}+\rho E C M_{t-1}+\varepsilon_{2 t}--------(2 . .10)
\end{aligned}
$$

The models from equations 2.9 and 2.10 have $\varphi$ and $\alpha$ as intercepts while $\bar{\sigma}_{p}, \bar{\omega}_{f}, \bar{\sigma}_{v}$ and $\Omega_{p,} \Omega_{f,} \Omega_{v}$ are the dynamic coefficients of the short-run with $\Delta$ as the first difference operator. All variables in equations 2.9 and 2.10 retained their explanations as earlier given above. However, $E C M_{t-1}$ is the one period lagged error correction term whose answer must be negative; $\delta$ and $\rho$ depicts the convergence speed to equilibrium after- shock. The ECM model is derived from ARDL by simple conversion of short-run with the long-run estimates without losing some essential information (Banerjee et al. 1993). Worthy of note is that, the value of $\delta$ and $\rho$ vary between -1 and 0 . When the coefficient is -1 , there is a sudden and complete convergence while 0 implies no meeting after experiencing the shock. The goodness of fit of the model can be checked through post-diagnostic test like serial correlation, functional form, normality test, heteroskedasticity and stability test such as Cumulative sum of Recursive Residuals (CUSUM) and Cumulative Sum of squares of Recursive Residuals (CUSUMSQ). 


\section{Empirical Results}

\subsection{Unit Root Test}

Before applying the ARDL bound test that operates on the premise of the variables being I(1) or I(0) process, the order of integration of the model need to be decided so as to avoid having a specious results. Owing to this assumption, variables integrated of order beyond I(1) say I(2) cannot be adequately interpreted within the F-statistic critical values provided by Pesaran et al. (2001). Therefore, this study employ Dickey-Fuller generalized least square (DF-GLS) detrending test proposed by Elliot, Rothenberg and Stock (1996). The choice of DF-GLS is necessitated by its performance in terms of sample size and strength.

From table 3.1 below, the DF-GLS unit root test results revealed that, all the variables are I(1) or the variables are stationary after the first difference. Thus, the null hypothesis of all the variables having unit root is rejected based on Schwarz Bayesian information Criteria (SBC) at 5 percent level of significance. In both model one and two, the optimal lag used is four (4) as decided by SBC.

Table 3.1 DF-GLS Unit root test

\begin{tabular}{c|c|c|c|c|c}
\hline \multirow{2}{*}{ Variables } & \multicolumn{2}{|c|}{ At level } & \multicolumn{2}{c|}{ First difference } & \multirow{2}{*}{ Order of integration I(1) } \\
\cline { 2 - 5 } & DF-GLS t-statistic & Critical val. (5\%) & DF-GLS t-statistic & Critical val. (5\%) & \\
\hline ER & -2.088 & -3.0010 & $-4.8918^{\star *}$ & -1.9433 & \\
\hline IR & -2.4410 & -3.0010 & $-4.8834^{\star *}$ & -1.9433 & $\mathrm{I}(1)$ \\
\hline $\mathrm{Db}$ & -2.6960 & -3.0010 & $-3.3726^{\star *}$ & -1.9433 & $\mathrm{I}(1)$ \\
\hline $\mathrm{Gd}$ & -2.1001 & -3.0010 & $-4.5200^{\star *}$ & -1.9433 & $\mathrm{I}(1)$ \\
\hline
\end{tabular}

Mackinnon (1996) at 5\% level of significance

From table 3.1 above, ${ }^{* *}$ explains rejection of the null hypothesis at $5 \%$ level of significance

The DF-GLS statistic are compared to the critical values from the replicated Mackinnon table in ERS (1996).

\subsection{ARDL-Bound Test for Cointegration}

The ARDL-bound test for cointegration was used on equations 2.5 and 2.6 for exchange rate and interest rate to establish if a sustained long-run association exists between the variables. In the Cointegrating test, the $\mathrm{F}$ and $\mathrm{t}$-statistics will be compared against the critical values of $F$ and $t$ for ARDL technique using the unrestricted error correction model (UECM).

Table 3.2 ARDL-bounds test result for cointegration of exchange rate

\begin{tabular}{|l|c|c|c|c|c|}
\hline T-statistic & Value & K & Level of sig. & \multicolumn{2}{|c|}{$\begin{array}{c}\text { Bound critical value } \\
\text { I(0) }\end{array}$} \\
& & & & $(1)$ \\
\hline \multirow{3}{*}{ F-Statistic. } & 4.9827 & 2 & $1 \%$ & 5.15 & 6.36 \\
\cline { 2 - 6 } & 4.9827 & 2 & $5 \%$ & 3.79 & 4.85 \\
\cline { 2 - 6 } & 4.9827 & 2 & $10 \%$ & 3.17 & 4.14 \\
\hline
\end{tabular}

Table 3.3 ARDL -bounds test result for cointegration of interest rate

\begin{tabular}{|l|c|c|c|c|c|}
\hline T-statistic & Value & K & Level of sig. & \multicolumn{2}{|c|}{$\begin{array}{c}\text { Bound critical value } \\
\text { I(0) }\end{array}$} \\
\hline \multirow{3}{*}{ F-Statistic. } & 4.7438 & 2 & $1 \%$ & 5.15 & 6.36 \\
\cline { 2 - 6 } & 4.7438 & 2 & $5 \%$ & 3.79 & 4.15 \\
\cline { 2 - 6 } & 4.7438 & 2 & $10 \%$ & 3.17 & 4.04 \\
\hline
\end{tabular}

Note: Where $\mathrm{K}$ depicts the number of independent variables in the ARDL models.

From tables 3.2 and 3.3 above, the estimated F-statistics are 4.9827 and 4.7438 respectively for exchange and interest rates which are both higher than the upper bound critical values at $5 \%$ level of significance (that is $/ 4.9827 / / 4.7438 />$ $14.85 / / 4.15 /)$. This means that, the null hypothesis of no cointegration is rejected at $5 \%$ level of significance. Hence, long- 
run relationship streams from exchange rate $(E R)$ to government budget deficit $(\mathrm{Gd})$ and government debt $(\mathrm{Db})$ on one hand and from interest rate (IR) to government budget deficit (Gd) and government debt (Db) on the other hand.

Furthermore, the coefficients of the long-run associations culminating to error correction model (ECM) have been estimated using ARDL approach. The estimated coefficients of the long-run association between exchange and interest rate as well as its control variables are as shown in Table 3.4

Table 3.4 Estimated long-run coefficients of model one and two

\begin{tabular}{c|c|c|c|c|c|c}
\hline \multicolumn{3}{c|}{ Exchange rate as dependent variable } & \multicolumn{3}{c}{ Interest rate as dependent variable } \\
\hline Variable & Coefficient & t-value & Prob. Val & Coefficient & t-Value & Prob. Val \\
\hline $\mathrm{C}$ & 9.398791 & 3.058834 & 0.0027 & 12.66301 & 25.89806 & 0.0000 \\
\hline $\mathrm{Gd}$ & -1.030006 & -0.104920 & 0.9166 & 7.790006 & 4.979136 & 0.0000 \\
\hline $\mathrm{Db}$ & 0.022592 & 16.15550 & 0.0000 & 0.000789 & 3.544431 & 0.0005 \\
\hline
\end{tabular}

From table 3.4 above, government budget deficit is negative and statistically insignificant in influencing exchange rate. This imply that, any 1 percent increase in government budget deficit results to a 103 percent fall in exchange rate in Nigeria. On the other hand, government debt is significant and influences exchange rate positively. Thus, any 1 percent increase in government debt cause exchange rate to augment by 2 percent. By inference, government debt though positive but have a lesser impact on the variation in Nigeria's exchange rate.

Furthermore, in the second model having interest rate as the dependent variable both government budget deficit and government debt has positive and significant impact on interest rate in Nigeria. Unambiguously, any 1 percent rise in government budget deficit and government debt lead to 78 and 1 percent increase in interest rate respectively. This result concurred to the findings of Odionye and Uma, (2013); Evans, (1987); Laumas, (1989); Muhammad and Mosood, (2012) supporting a priori expectation of Keynesian hypothesis which upholds that, an increase in government budget deficit and government debt increases interest rate and other macroeconomic variables since most shortfalls are funded via debts.

\subsection{Dynamics of short-run error correction}

Since all the variables are cointegrated after the first difference, there is need to restore deviations that may influence the model towards equilibrium. The short-run dynamics of the ARDL- error correction model is decided by SBC criterion of $\operatorname{ARDL}(2,2,2)$ and $\operatorname{ARDL}(2,0,0)$ for model one and two as shown in tables 3.5 and 3.6 below:

Table 3.5 Results of Error correction model with exchange rate (Er) as the dependent variable decided by SBC-ARDL (2, 2, 2) model.

\begin{tabular}{l|c|c|c}
\hline Variable & Coefficient & $\mathrm{t}$-statistic & Prob-value \\
\hline $\mathrm{D}(\mathrm{ER}(-1))$ & 0.629965 & 8.642106 & 0.0000 \\
\hline $\mathrm{D}(\mathrm{GD})$ & -0.000039 & -6.519159 & 0.0000 \\
\hline $\mathrm{D}(\mathrm{GD}(-1))$ & 0.000026 & 3.689735 & 0.0003 \\
\hline $\mathrm{D}(\mathrm{DB})$ & 0.013303 & 8.138655 & 0.0000 \\
\hline $\mathrm{D}(\mathrm{DB}(-1))$ & -0.009237 & -5.008309 & 0.0000 \\
\hline $\mathrm{ECM}(-1)$ & -0.018068 & -1.758801 & 0.0811 \\
\hline $\mathrm{ECM}=\mathrm{ER}-\left(0.0001^{*} \mathrm{GD}+0.0317^{*} \mathrm{DB}+13.3859\right)$ \\
$\begin{array}{l}\text { Durbin Watson }=1.035804 \\
\text { F-stat (Prob. Val) }=0.0000\end{array}$ \\
\hline
\end{tabular}

The table above explained how shocks in the model can be corrected towards equilibrium after short-run deviations. The lagged coefficient of the ECM $(-0.018068)$ fulfils the negativity premise but is insignificant $(-1.758801)$ in restoring the seeming deviations to equilibrium. By implication, if exchange rate is at disequilibrium, it can be returned back to equilibrium at 1 percent after every four months in the last four years in Nigeria as chosen by SBC. The coefficient of determination

$\mathrm{R}^{2}(0.852972)$ is strong in clarifying the change in exchange rate as determined by the control variables. The Durbin-Watson is greater than the coefficient of determination (/1.035804/ $>/ 0.852972 /)$ which means that, the model is not serially correlated as proven by the probability of the f-statistic that is lesser than $5 \%$ level of significance. 
Table 3.6 Results of Error correction model with interest rate (Ir) as the dependent variable decided by SBC-ARDL (2, 0 , 0) model.

The table below described how the lagged coefficient of the error correction model ECM (-0.085509) estimated from $\operatorname{SBC-ARDL}(2,0,0)$ model is negative and significant $(-3.249014)$ fulfilling the underlying assumption of ECM. This means that, if interest rate deviated from equilibrium in Nigeria, it can be reinstated by $8 \%$ in every quarter of the four years decided by SBC. Also, the disparity in interest rate can be explained by $67 \%$ change in the control variables alongside a justifiable model free of serial correlation unraveled by the Durbin-Watson that is greater than the coefficient of determination $\mathrm{R}^{2}(0.916480>0.663200)$.

\begin{tabular}{|c|c|c|c|}
\hline Variable & Coefficient & t-statistic & Prob. Value \\
\hline $\mathrm{D}(\mathrm{IR}(-1))$ & 0.513401 & 6.695441 & 0.0000 \\
\hline $\mathrm{D}(\mathrm{GD})$ & 0.000000 & 0.824153 & 0.4114 \\
\hline $\mathrm{D}(\mathrm{DB})$ & 0.000013 & 0.185398 & 0.8532 \\
\hline ECM(-1) & -0.085509 & -3.249014 & 0.0015 \\
\hline \multicolumn{4}{|c|}{$\begin{array}{l}E C M=I R-\left(0.0000^{*} G D+0.0001 * D B+13.7492\right) \quad R^{2}=0.663200 \\
\text { Durbin-Watson stat. }=0.916480 \text { Adjusted } R^{2}=0.650226 \mathrm{~F} \text { stat }(\text { Prob. Val })=0.000010\end{array}$} \\
\hline
\end{tabular}

To confirm that Ricardian Equivalence Hypothesis (REH) hold in Nigeria, the restrictions of the null hypothesis $\lambda_{2}=\lambda_{3}=0$ and $\phi_{2}=\phi_{3}=0$ must be satisfied from equations 2.5 and 2.6 via the coefficients of the standard Wald-test as described below.

Table 3.7 Standard Wald-test results

\begin{tabular}{|c|c|c|c|c|c|c|}
\hline \multirow[b]{3}{*}{ Test statistic } & \multirow{2}{*}{\multicolumn{2}{|c|}{\begin{tabular}{|c|} 
Model one (ER as dep variable) \\
$\mathrm{H} 0: \mathrm{Gd}=\mathrm{Db}=0$
\end{tabular}}} & \multirow{2}{*}{\multicolumn{2}{|c|}{\begin{tabular}{|c|} 
Model two(IR as dep variable) \\
$\mathrm{H} 0: \mathrm{Gd}=\mathrm{Db}=0$
\end{tabular}}} & \multirow{2}{*}{\multicolumn{2}{|c|}{ Pesaran F-stat.C1(iii) }} \\
\hline & & & & & & \\
\hline & value & Prob. & Value & Prob. & Lower bounds & Upper bounds \\
\hline F-statistic & 76.28298 & 0.0000 & 7.68863 & 0.0002 & \multirow[b]{2}{*}{3.79} & \multirow[b]{2}{*}{4.85} \\
\hline$\overline{X^{2} \text {-statistic }}$ & 152.5660 & 0.0000 & 12.37270 & 0.0000 & & \\
\hline
\end{tabular}

The result of the Wald-test above revealed that, the F-calculated from model one and two (/76.28298//7.68863/) fall above upper bounds (4.85) as decided by Pesaran et al. (2001) critical table C1(iii). Thus, the null hypothesis of government budget deficit and government debt equals zero should be rejected. By inference, the restrictions are not equal to zero which counteracted the validity of REH in Nigeria using high frequency data from 1981Q1 to 2013 Q4.

These outcomes are in line with the study of Waqas, Awan \& Aslam (2011); Muhammad \& Mosood (2011); and Kazmi $(1992,2001)$.

The reliability of the core post-diagnostic test from ARDL equations 2.9 and 2.10 fit the models and has been checked at $5 \%$ level of significance as demonstrated in table 3.8 below:

Table 3.8 Post-diagnostic test from equations 2.9 and 2.10

\begin{tabular}{l|c|c|c|c}
\hline \multirow{2}{*}{ LM t-statistic } & \multicolumn{2}{|c|}{ MODEL ONE } & \multicolumn{2}{c}{ MODEL TWO } \\
\cline { 2 - 5 } & Chi stat. X & Prob.Val & Chi stat. X & Prob. Val \\
\hline Serial correlation(*) & 2.564695 & 0.7044 & 2.589114 & 0.5740 \\
\hline Heteroscedasticity(**) & 27.45601 & 0.8168 & 17.44674 & 0.7916 \\
\hline Jarque-Bera (*** & 11.571451 & 0.6514 & 17.09101 & 0.7038 \\
\hline Functional form(***) & F-stat.(2,126) 221.887 & 0.6917 & F-stat. $(1,123) 5.1412$ & 0.6251 \\
\hline
\end{tabular}

Note: Where $\left({ }^{*}\right),\left(^{* \star}\right),\left(^{\star \star *}\right)$ and $\left({ }^{* \star \star}\right)$ denotes Breusch-Godfrey LM test for serial correlation, Breusch-Pagan Godfrey heteroscedasticity test, Jarque-Bera Normality test and Ramsey RESET test for omitted variables respectively.

Moreover, In case of exchange and interest rate that are always termed as model one and two above, the probability of the chi square $\left(\mathrm{X}^{2}\right)$ and F-statistic are greater than $5 \%$ level of significance. Therefore, it can be concluded that, the models are not serially correlated, no heteroskedasticity, the residuals are normality distributed as dictated by JarqueBera and there is no error in specifying the model. Also, the models are stable over the study period 1981Q1 to 2013Q4 as can be seen inthe Cumulative sum of the recursive residuals (CUSUM) and cumulative sum of Squares of the recursive residuals (CUSUMSQ) tests depicted in appendix 5 where the ridges moved within the critical bounds. 


\section{Conclusion}

The study examined the validity of Ricardian Equivalence Hypothesis by analyzing the impact of exchange and interest rates on government budget deficit and government debt between 1981Q1 and 2013Q4 using Autoregressive Distributed Lag (ARDL) bounds method. The short and long-run dynamics between the variables were verified. The estimation results from exchange rate, interest rate, government budget deficit and government debt via the model and standard Wald-test refuted the validity of Ricardian Equivalence Hypothesis in Nigeria. The study emphatically stressed out that, government budget deficit and government debt are not equals zero because Nigerian consumers are not Ricardian but Keynesians in orientation. Fiscal policy is effective in macroeconomic stabilization. Therefore, consumers treat government debt as net wealth by increasing their consumption of goods and services as their disposable income increases due to cut in tax or borrowing. Since government budget deficit have strong and positive impact on interest rate in Nigeria, it can be recommended that government should concentrate on the appropriate fiscal policy mix using the right internal and external debt ratio as means of financing shortfall. Also, pervasive rise in general price level and interest rate in Nigeria can be curbed by using preventive monetary, fiscal and exchange rate policies.

\section{References}

Adji, A. (2007). Essays on Ricardian Equivalence. Retrieved from http://scholarworks.gsu.edu/econs_diss/19 on 11th June, 2015.

Afonso, A. (2008). Euler Testing Ricardo and Barro in the EU. School of Economics and Management, Technical University of Lisbon. Working paper 23

Afzal, M. (2012). "Ricardian Equivalence hypothesis: Evidence from Pakistan". E3 Journal of Business Management and Economics, 3(6): $258-265$.

Akanbi, S. B. (Nd). "Ricardian Equivalence and Nigerian economy: An Empirical Investigation", Department of Economics, University of Ilorin, Nigeria, 17(1), 45-60.

Banerjee, A., Dolado, J., Galbraith, J. W., \& Hendry, D. F. (1993). Cointegration, Error correction and Econometric Analysis of Nonstationary Data. Oxford: Oxford University Press.

Barro, R. J. (1974). "Are government bonds net wealth?" Journal of Political Economy, 82(6): 1095 - 1117.

Central Bank of Nigeria (2013). Annual Reports and Statement of Accounts. Abuja: Central Bank of Nigeria.

Elliot, G., Rothenberg, T. J., Stock, J. H. (1996). "Efficient Tests for an Autoregressive Unit Root", Econometrica, 64, 813-36.

Engle, R. F. \& Granger, C. E. J. (1987). "Cointegration and Error Correction Representation: Estimation and Testing", Econometrica, 55(2): 251-276.

Evans, P. (1987). "Do Budget Deficits Raise Nominal Interest Rates?" Journal of Monetary Economics, 20(2): 281-300.

Johansen, S. \& Juselius, K. (1995). "Maximum Likelihood Estimation and Inference on Cointegration with the Application on Demand for Money", Oxford Bulletin of Economics and Statistics, 52, 169-210.

Kazimi, A. A. (1992). "Ricardian Equivalence: Some Macro-econometric Tests For Pakistan", The Pakistan Development Review, 31(4): 733-758.

Kazmi, A. A. (2001). "Ricardian Equivalence Hypothesis: some Empirical Tests for Pakistan Based on Blanchard-Evans Models", The Lahore Journal of Economics, 6, 75-92.

Laumas, G. S. (1989). "Anticipated Federal Budget Deficits, Monetary Policy and the Rate of Interest", Southern Economic Journal, 56(2): $375-382$.

Likita, O. (2014). "Econometric Test of Ricardian Equivalence Hypothesis: Results for Nigeria", JORIND 12(1), www.ajol.infoljournals/ jorind.

Marinheiro, C. F. (2001). "Ricardian Equivalence: An Empirical Application to the Portuguese Economy". CES Discussion Paper Series, Katholieke Universiteit Leuven, No. 01.12.http://www.econ.kuleuven.be/ces/discussionpapers/default.htm.

Muhammad, W., \& Mosood, S. A. (2012). "Exchange rate, Interest rate and Ricardian Equivalence Hypothesis Evidence from Pakistan", The Romanian Economic Journal, 46, 249-270.

Muhammed, W., \& Moshood, S. A. (2011). "Are Pakistani Consumers Ricardian?"Journal of Economics of Business Review, 13(3): 161177.

Odionye, J. C., \& Uma, K. E. (2013). "The Relationship between Budget Deficit and Interest Rate: Evidence from Nigeria". European Journal of Business and social Sciences, 2(1): 158-167.

Orji, U. O., Onyeze, C. N., \& Edeh, L. (2014). "The Keynesian-Ricardian Dichotomy on budget deficits in Nigeria". Journal of Economics and finance,5(2): $69-78$.

Oseni, I. O., \& Olomola, P. A. (2013). "Testing the validity of Ricardian Equivalence Hypothesis in Nigeria", International Journal of Business and Economic Research, 1(1): 164- 174.

Ouattara, B. (2004). Foreign Aid and Fiscal Policy in Senegal. Mimeo University of Manchester.

Pesaran, M. H., Shin, Y., \& Smith, R. J. (2001). "Bounds Testing Approaches to the Analysis of Level Relationships", Journal of Applied Econometrics, 16, 289-326.

Rodrigues, P. C. (2006). "The Ricardian Equivalence Proposition in OECD Countries: Does Government Debt weight Down 
Growth?"Thesis submitted to the School of Economics, University of Nottingham, Nottingham, 1-12. Retrieved online from http://ssrn.com/abstract on 20/11/2015

Tito, B. S. M., Geraldo, D. S., \& Fernando, A. R. S. (2001). "Are Government Bonds net Wealth? Some Empirical Evidence", Modern Economy, 2, 413-415.

Waqas, M., Awan, M. S., \& Aslam, M. A. (2011). "We are Living on the Cost of Our Children", Interdisciplinary Journal of Cotemporary Research in Business, 2, 607-623.

\section{APPENDICES}

APPENDIX 1: Serial Correlation

Model 1

Breusch-Godfrey Serial Correlation Lm Test

\begin{tabular}{lccc}
\hline \hline F-statistic & 1.197465 & Prob. F(2,119) & 0.3056 \\
Obs*R-squared & 2.564695 & Prob. Chi-Square(2) & 0.7044 \\
\hline \hline Model 2 & & \\
Breusch-Godfrey Serial & Correlation Lm Test & & \\
\hline \hline F-statistic & 1.249740 & Prob. F(2,123) & 0.7902 \\
Obs*R-squared & 2.589114 & Prob. Chi-Square(2) & 0.5740
\end{tabular}

APPENDIX 2: Heteroskedasticity

\section{Model 1}

Heteroskedasticity Test: Breusch-Pagan-Godfrey

\begin{tabular}{lccc}
\hline \hline F-statistic & 2.204103 & Prob. F(14,113) & 0.5015 \\
Obs*R-squared & 27.45601 & Prob. Chi-Square(14) & 0.8168 \\
Scaled explained SS & 153.9902 & Prob. Chi-Square(14) & 0.0000 \\
\hline \hline
\end{tabular}

\section{Model 2}

Heteroskedasticity Test: Breusch-Pagan-Godfrey

\begin{tabular}{lccc}
\hline \hline F-statistic & 4.844025 & Prob. F(4,125) & 0.6812 \\
Obs*R-squared & 17.44674 & Prob. Chi-Square(4) & 0.7916 \\
Scaled explained SS & 128.9414 & Prob. Chi-Square(4) & 0.0000
\end{tabular}

APPENDIX 3. Functional Form

\section{Model 1}

RAMSEY RESET Test

Specification: ER C GD DB

Omitted Variables: Powers of fitted values from 2 to 3

\begin{tabular}{lccc}
\hline \hline & Value & df & Probability \\
\cline { 2 - 4 } F-statistic & 221.8878 & $(2,126)$ & 0.6917 \\
Likelihood ratio & 199.1828 & 2 & 0.6714 \\
\hline \hline
\end{tabular}

\section{Model 2}

RAMSEY RESET Test

Specification: IR IR(-1) IR(-2) GD DB C

Omitted Variables: Squares of fitted values

\begin{tabular}{lccc}
\hline \hline & Value & $\mathrm{df}$ & Probability \\
\cline { 2 - 4 } t-statistic & 2.267440 & 123 & 0.5100 \\
F-statistic & 5.141283 & $(1,123)$ & 0.6251
\end{tabular}


APPENDIX 4: Normality Test

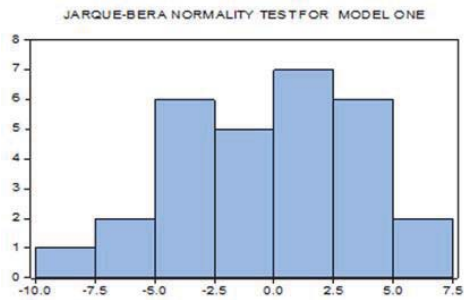

\begin{tabular}{|lc|}
\hline \multicolumn{2}{|l|}{ Series: Residuals } \\
Sample 198101 201304 \\
Observations 132 \\
Mean & $-9.40 e-14$ \\
Median & 0.187523 \\
Mavimum & 7.373752 \\
Mnimum & -8.240502 \\
Std. Dev. & 3.830105 \\
Skewness & -0.134222 \\
Kurtosis & 2.386862 \\
Jarque-Bera & 11.571451 \\
Probability & 0.051469 \\
\hline
\end{tabular}

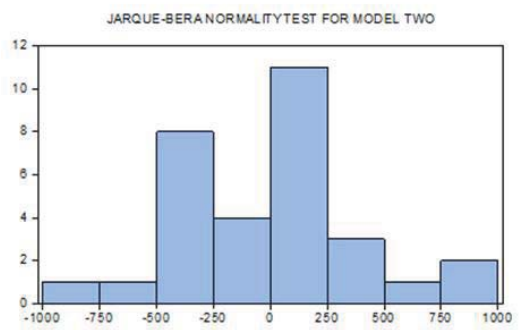

Series: Residuals Sample 1981Q1 2013Q4 Observations 132

Mean $\quad 8.18 \mathrm{e}-13$

Maximum $\quad 995.018$

Minimum 791.3527

Std. Dev. $\quad 403.983$

$\begin{array}{ll}\text { Skewness } & 0.390647 \\ \text { Kurtosis } & 2.977747\end{array}$

Jarque-Bera $\quad 17.0910$

Probability 0.70383

APPENDIX 5: Stability Test
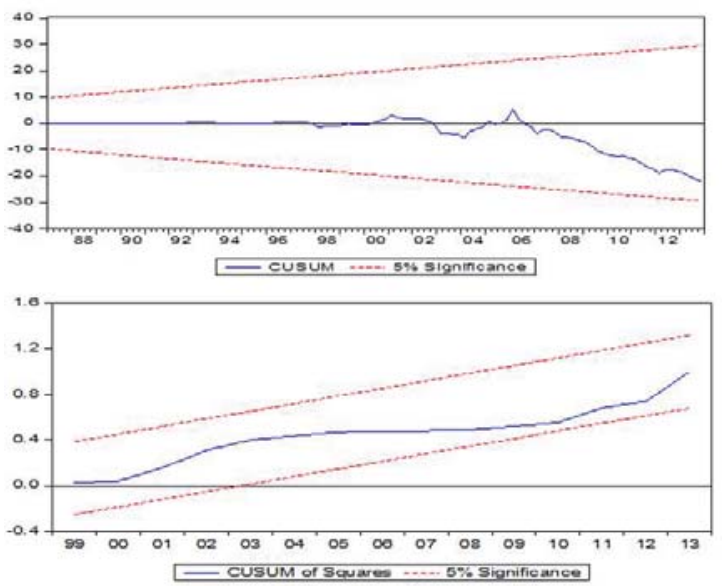